\title{
KERAGAAN KOPERASI SUSU DAN PENDAPATAN USAHA TERNAK SAPI PERAH: SEBUAH STUDI DI KPSBU LEMBANG
}

\author{
Leo Rio Ependi Malau ${ }^{*}{ }^{* 1)}$, Ratna Winandi Asmarantaka ${ }^{2)}$, Suharno ${ }^{2)}$ \\ 1) Balai Penelitian dan Pengembangan Lingkungan Hidup dan Kehutanan Palembang, Palembang \\ Indonesia \\ 2) Departemen Agribisnis, Fakultas Ekonomi dan Manajemen, IPB University, Bogor, Indonesia \\ *) E-mail Penulis Korespondensi: leoriomalau62@gmail.com
}

\begin{abstract}
ABSTRAK
Koperasi susu merupakan kelembagaan yang berperan penting dalam agribisnis susu di Indonesia. Salah satu koperasi susu yang sukses di Indonesia yaitu KPSBU Lembang. Pesatnya perkembangan KPSBU Lembang penting untuk dipelajari sebagai benchmark bagi koperasi susu lainnya dalam upaya meningkatkan produksi susu nasional. Penelitian ini bertujuan untuk: (1) mendeskripsikan keragaan KPSBU Lembang; (2) menganalisis peran KPSBU Lembang dan (3) menganalisis pendapatan usahaternak sapi perah anggota KPSBU Lembang. Penelitian dilakukan di KPSBU Lembang, Kabupaten Bandung Barat, dengan jumlah responden sebanyak 95 peternak. Metode analisis data yang digunakan yaitu teknik skoring, rasio keuangan dan pendapatan usahaternak. Hasil penelitian menunjukkan KPSBU Lembang mengalami perkembangan yang pesat terlihat dari pertambahan jumlah anggota, volume usaha, produksi susu, modal dan SHU. Unit-unit usaha yang dikembangkan KPSBU Lembang juga sudah sesuai kebutuhan anggota. Kinerja keuangan koperasi tergolong tidak baik namun persentase biaya operasional yang relatif efisien dan digunakan untuk mendukung usaha anggota mengindikasikan kondisi keuangan masih dalam kategori wajar.Penilaian dari anggota menunjukkan KPSBU Lembang berdampak positif terhadap kinerja usaha anggotanya. Hal ini terlihat dari besaran pendapatan dan rasio R/C yang mengindikasikan bahwa usahaternak sapi perah tersebut layak dan menguntungkan. Hasil penelitian ini berimplikasi bahwa pengoptimalan peran koperasi susu dapat menjadi salah satu solusi peningkatan produksi susu nasional.
\end{abstract}

Kata kunci: Koperasi Susu; Peran; Pendapatan; Usahaternak Sapi Perah.

\section{PENDAHULUAN}

Susu merupakan salah satu sumber protein hewani yang mengandung nutrisi lengkap dan seimbang yang berperan dalam pembentukan tulang dan gigi serta dibutuhkan tubuh sebagai zat pembangun, terutama pada masa pertumbuhan (Syarif dan Harianto, 2011). Sapi perah merupakan penghasil susu yang sangat dominan dibandingkan ternak perah lainnya dan sangat besar kontribusinya dalam memenuhi konsumsi susu manusia (Makin, 2011). Perkembangan populasi sapi perah sebagai hewan utama penghasil susu di Indonesia cenderung meningkat setiap tahunnya. peningkatan tersebut juga diikuti dengan peningkatan produksi susu nasional. Namun peningkatan produksi susu tersebut tidak menjamin bahwa seluruh kebutuhan susu dalam negeri dapat dipenuhi oleh produksi domestik. Data tahun 2009-2018 menunjukkan bahwa rata-rata produksi susu nasional hanya mampu memenuhi 22,76 persen kebutuhan nasional sedangkan sisanya sebesar \pm 77 persen dipenuhi dengan cara mengimpor dari negara lain (Pusdatin, 2019). Bahkan jumlah impor susu Indonesia 
cenderung mengalami peningkatan setiap tahunnya sehingga dapat disimpulkan bahwa produksi susu Indonesia cenderung stagnan.

Usaha peternakan sapi perah di Indonesia di dominasi oleh peternakan sapi perah rakyat dengan manajemen tradisional dan skala kepemilikan yang belum ekonomis dengan produksi susu yang masih rendah (Utami et al., 2020; Asmara et al., 2016). Meskipun skala usaha peternakan rakyat relatif kecil, kontribusi usaha peternakan sapi perah rakyat terhadap produksi nasional mencapai sekitar 90 persen.Hal ini disebabkan peternakan rakyat jumlahnya sangat banyak.

Tabel 1. Perkembangan Produksi Susu Nasional Tahun 2009 s.d 2018

\begin{tabular}{cccccc}
\hline Tahun & $\begin{array}{c}\text { Jumlah } \\
\text { sapi perah } \\
\text { (Ekor) }\end{array}$ & $\begin{array}{c}\text { Produksi } \\
\text { susu } \\
\text { (Ton) }\end{array}$ & $\begin{array}{c}\text { Kontribusi susu } \\
\text { nasional terhadap } \\
\text { konsumsi (\%) }\end{array}$ & $\begin{array}{c}\text { Kontribusi } \\
\text { impor terhadap } \\
\text { konsumsi (\%) }\end{array}$ & $\begin{array}{c}\text { Impor } \\
\text { (Ton) }\end{array}$ \\
\hline 2009 & 474.701 & 827.249 & 25,99 & 74,01 & 211.634 \\
2010 & 488.449 & 909.533 & 24,15 & 75,85 & 231.396 \\
2011 & 597.213 & 974.694 & 23,51 & 76,49 & 247.495 \\
2012 & 611.939 & 959.732 & 20,88 & 79,12 & 386.116 \\
2013 & 444.266 & 786.646 & 20,79 & 79,21 & 380.558 \\
2014 & 502.516 & 800.751 & 19,02 & 80,98 & 365.186 \\
2015 & 518.649 & 835.125 & 19,37 & 80,63 & 368.844 \\
2016 & 533.933 & 912.735 & 19,21 & 80,79 & 237.484 \\
2017 & 540.441 & 928.108 & 26,46 & 75,34 & 223.855 \\
2018 & 581.822 & 996.442 & 25,87 & 74,13 & 256.657 \\
\hline
\end{tabular}

Sumber: Pusdatin (2019)

Berbagai kendala yang dihadapi peternakan sapi perah rakyat seperti skala usaha yang belum ekonomis, posisi tawar yang lemah dan keterampilan teknis budidaya yang kurang memadai sehingga sulit bagi peternak untuk mengelola usahaternaknya secara efisien.Skala usaha yang kecil dan tidak ekonomis juga berpengaruh terhadap rendahnya produktivitas dan lemahnya posisi tawar (bargaining position)peternak. Kehadiran koperasi susu sebagai representasi peternak merupakan soluasi dari permasalahan yang dihadapi oleh peternak sapi perah. Peran koperasi susu dalam menyediakan input produksi (saprodi), penyedia kredit, inseminasi buatan (IB), pemasaran susu, melakukan penyuluhan, pembinaan dan pelatihan kepada peternak menjadi penting diperhatikan untuk mendukung kinerja usahaternak sapi perah anggota koperasi sehingga upaya peningkatan produksi susu nasional dapat terwujud.

Salah satu koperasi susu dengan produksi susu dan populasi sapi perah terbesar di Indonesia yaitu Koperasi Peternak Sapi Perah Bandung Utara (KPSBU) Lembang, di Kabupaten Bandung Barat. Peran KPSBU Lembang dalam pengembangan usahaternak sapi perah terlihat dari layanan usaha yang disediakan koperasi seperti pembinaan peternak, penyedia fasilitas kredit, penyediaan pakan konsentrat, mineral, obat-obatan dan vitamin, pelayanan medis ternak, inseminasi buatan (IB), pemasaran susu serta sebagai fasilitator dan mediator bantuan pihak ketiga. Penyediaan input produksi yang dilakukan koperasi memungkinkan peternak dapat memeroleh input dengan harga lebih terjangkau, pasokan lebih terjamin dan berkesinambungan serta kualitas input yang lebih baik. Pemasaran susu secara kolektif melalui koperasi juga diharapkan dapat menciptakan pengehamatan biaya dan meminimalisasi biaya transaksi dibandingkan jika melakukan pemasaran susu secara perorangan. Berdasarkan mekanisme kerja tersebut diharapkan peternak dapat memperbaiki posisi tawar, baik dalam memasarkan hasil produksi maupun dalam pengadaan input produksi.

Melalui hubungan yang terjalin antara koperasi susu dan peternak diharapkan berguna dalam meningkatkan pengetahuan, ketermapilan dan sikap serta tumbuh dan berkembangnya kemandirian dalam melakukan usahaternak dengan produktivitas yang meningkat dan pendapatan yang bertambah (Ortmann dan King 2007; Sarker dan Ghosh 
2011; Hermanto dan Swastika, 2011; Asih et al. 2013; Ariningsih 2014). Simelane (2011) menambahkan bahwa koperasi susu berkontribusi penting dalam meningkatkan produktivitas sapi perah anggota melalui berbagai perannya dalam menyediakan layanan input produksi, alat dan mesin pertanian, kredit, penyuluhan, pendidikan anggota, pemasaran susu dan kegiatan lainnya. Selain itu, melalui berbagai pelatihan, pembinaan dan kemudahan dalam memeroleh input produksi oleh koperasi sehingga dimungkinkan untuk menghasilkan kualitas susu yang lebih baik dan berdampak pada harga susu yang diterima peternak menjadi lebih tingggi. Secara keseluruhan peran koperasi akan berdampak positif terhadap kinerja usahaternak sapi perah anggota.

Keunikan koperasi susu yaitu seluruh anggotanya merupakan peternak sapi perah yang dalam hubungannya dengan koperasi merupakan sebagai pengusaha dan posisinya sangat strategis dalam mendukung berjalannya kehidupan usaha dan organisasi koperasi. Partisipasi ekonomi anggota berupa simpanan pokok, wajib dan sukarela kepada koperasi merupakan sumber modal utama bagi koperasi susu. Modal tersebut kemudian digunakan untuk membuka usaha dan mendapatkan keuntungan dan selanjutnya keuntungan tersebut juga akan kembali kepada anggota.

Keberhasilan KPSBU Lembang sebagai salah satu koperasi susu terbesar di Indonesia secara langsung merupakan keberhasilan peternak anggota. Salah satu indikasi keberhasilan KPSBU Lembang dalam bisnis susu segar terlihat dari pertambahan jumlah anggota setiap tahunnya dalam kurun waktu 2011-2016. Peran KPSBU Lembang yang terbukti mampu mendukung kinerja usaha anggotanya menjadi insentif dan motivasi bagi peternak lainnya untuk bergabung dalam koperasi.Salah satu ukuran kinerja yang dapat digunakan untuk menilai keberhasilan usahaternak sapi perah anggota koperasi yaitu tingkat profitabilitas atau pendapatan usaha. Keberadaan KPSBU Lembang yang terbukti mampu berpengaruh positif terhadap kinerja usahaternak sapi perah anggota berimplikasi bahwa KPSBU Lembang dapat menjadi benchmark bagi koperasi susu lainnya sebagai salah satu upaya meningkatkan produksi susu nasional.

Keberhasilan KPSBU Lembang dalam mendukung kinerja usahaternak anggotanya penting untuk dipelajari agar dapat menjadi lesson learned bagi koperasi lainnya. Koperasi susu yang berhasil merupakan kombinasi antara manajemen yang baik dalam struktur kepengurusan koperasi, keberadaan bisnis-bisnis yang berhubungan langsung dengan usaha anggota dan peran koperasi yang optimal. Berdasarkan uraian diatas maka tujuan penelitian ini yaitu: (1) Mendeskripsikan keragaan KPSBU Lembang yang meliputi jenis layanan usaha dan kinerja keuangan; (2) Menganalisis peran KPSBU Lembang dalam pengembangan usahaternak sapi perah; dan (3) Menganalisis pendapatan usahaternak sapi perah anggota KPSBU Lembang.

\section{METODE}

Penelitian ini dilaksanakan di Koperasi Peternak Sapi Perah Bandung Utara (KPSBU) Lembang, Kabupaten Bandung Barat, Jawa Barat yang ditentukan dengan sengaja (purposive) karena merupakan salah satu koperasi susu terbesar di Indonesia. Pengumpulan data dilapangan dilakukan pada bulan Februari-April 2017.

Data primer yang digunakan dalam penelitian ini dikumpulkan melalui wawancara kepada peternak dan pengurus koperasi dengan panduan kuesioner.Data primer yang digunakan berupa keragaan usahaternak sapi perah dan variabel sosial-ekonmi peternak.Sedangkan data sekunder dikumpulkan dari berbagai sumber dan literatur sesuai dengan kebutuhan.

Populasi penelitian ini merupakan peternak anggota koperasi yang aktif menyetorkan susu ke KPSBU Lembang tahun 2016 yaitu sebanyak 4.041 peternak. Peternak tersebut tersebar di 26 Tempak Pelayanan Koperasi (TPK). Selanjutnya dipilih 6 TPK dengan jumlah peternak dan produksi susu terbesar. Alasan untuk memilih 6 TPK dengan jumlah peternak dan produksi susu terbesar dengan pertimbangan dari penyuluh dan pengurus koperasi serta diduga TPK tersebut memiliki kinerja yang lebih baik 
dibandingkan TPK lainnya. Dari 6 TPK tersebut, dipilih sebanyak 95 peternak sebagai responden yang ditentukan secara sengaja berdasarkan arahan dari penyuluh koperasi dan ketua kelompok.

Metode analisis yang digunakan dalam penelitian ini yaitu analisis kualitatif dan kuantitatif.Analisis kualitatif digunakan untuk mendeskripsikan keragaan layanan usaha koperasi dan karakteristik sosial-ekonomi peternak.Analisis kuantitatif digunakan untuk menganalisis pendapatan usahatani, peran koperasi dan kinerja keuangan. Analisis yang digunakan per tujuan penelitian diuraikan sebagai berikut:

1. Untuk mendeskripsikan keragaan KPSBU Lembang digunakan analisis deskriptif yaitu dengan mendeskripsikan layanan usaha dan kinerja keuangan.Kinerja keuangan koperasi yang dianalisis terdiri dari biaya-biaya, pendapatan, sisa hasil usaha (SHU) dan rasio-rasio keuangan seperti rasio likuiditas, rasio solvabilitas, Return on Investment (ROI), serta Return on Equity (ROE). Rasio likuiditas bertujuan untuk mengukut kemampuan koperasi dalam memenuhi kewajiban-kewajiban jangka pendeknya dengan aktiva lancar yang dimiliki (Munawir, 1995). Rasio solvabilitas mengukur kemampuan koperasi untuk membayar utang jangka panjang baik utang pokok maupun bunganya (Sartono, 2015). Rasio rentabilitas digunakan untuk mengukur profit yang diperoleh dari modal-modal yang digunakan untuk kegiatan operasional atau untuk mengukut kemampuan perusahaan dalam menghasilkan keuntungan (Munawir, 1995).

Tabel 2. Indikator Pengukuran Peran Koperasi Susu

\begin{tabular}{|c|c|c|}
\hline No & Indikator & Pengukuran \\
\hline 1. & $\begin{array}{l}\text { Production } \\
\text { support }\end{array}$ & $\begin{array}{l}\text { 1. Menyediakan sarana produksi (Konsentrat, IB layanan kesehatan } \\
\text { dan lainnya) } \\
\text { 2. Menyediakan kredit sapi rereongan } \\
\text { 3. Menyediakan fasilitas pinjaman } \\
\text { 4. Melakukan pelatihan dan pembinaan mengenai budidaya dan } \\
\text { teknologi } \\
\text { 5. Memfasilitasi bantuan pemerintah }\end{array}$ \\
\hline 2. & $\begin{array}{l}\text { Marketing } \\
\text { support }\end{array}$ & $\begin{array}{l}\text { 1. Menyediakan informasi pasar } \\
\text { 2. Pemasaran dan transportasi susu }\end{array}$ \\
\hline 3. & $\begin{array}{l}\text { Member } \\
\text { representation }\end{array}$ & $\begin{array}{l}\text { 1. Negosiasi harga dengan IPS } \\
\text { 2. Membangun jaringan kerjasama dengan pihak penyedia saprodi } \\
\text { dan permodalan } \\
\text { 3. Membangun jaringan kerjasama dengan pihak pemasaran dan } \\
\text { pengolahan hasil }\end{array}$ \\
\hline 4. & $\begin{array}{l}\text { Finance and } \\
\text { accounting }\end{array}$ & $\begin{array}{l}\text { 1. Mengelola administrasi keuangan dengan baik dan benar } \\
\text { 2. Transparansi dalam perhitungan keuangan }\end{array}$ \\
\hline 5. & $\begin{array}{l}\text { Group } \\
\text { management }\end{array}$ & $\begin{array}{l}\text { 1. Merencanakan dan mempersiapkan kebutuhan belajar bagi } \\
\text { anggota } \\
\text { 2. Menyelesaikan konflik antar anggota } \\
\text { 3. Mengadalam rapat dan pertemuan secara rutin } \\
\text { 4. Memahami keinginan, pendapat maupun masalah yang dihadapi } \\
\text { anggota } \\
\text { 5. Merumuskan kesepakatan bersama baik dalam memecahkan } \\
\text { masalah maupun untuk melakukan berbagai kegiatan koperasi } \\
\text { 6. Menciptakan suasana saling kenal, saling mempercayai antar } \\
\text { anggota } \\
\text { 7. Sebagai wadah untuk saling memberikan pendapat dan } \\
\text { menanyakan permasalahan tentang usahaternak sapi perah } \\
\text { 8. Menaati dan melakukan kesepakatan yang dihasilkan bersama }\end{array}$ \\
\hline
\end{tabular}

Sumber: Diadopsi \& dikembangkan dari Sonam \& Martwanna, (2013); Sulastri \& Maharjan, (2002) 
2. Untuk mengalisis peran koperasi dalam pengembangan usahaternak sapi perah digunakan teknik scoring dengan menggunakan lima indikator yang diadopsi dari penelitian Sonam dan Martwanna (2013); Sulastri dan Maharjan (2002). Indikator tersebut yaitu dukungan sarana produksi (production support), dukungan pemasaran (marketing support), pencatatan dan pengelolaan keuangan (finance and accounting), representasi anggota (member representation) dan manajemen kelompok (group management). Penjelasan setiap indikator disajikan secara lengkap pada Tabel 2.

3. Untuk menganlisis pendapatan usahaternak sapi perah anggota KPSBU Lembang digunakan analisis pendapatan usahatani dengan cara menganalisis stuktur biaya, penerimaan, pendapatan dan rasio $\mathrm{R} / \mathrm{C}$.

\section{HASIL DAN PEMBAHASAN}

\section{Keragaan Layanan Usaha dan Kinerja Keuangan KPSBU Lembang}

Koperasi Peternak Sapi Perah Bandung Utara (KPSBU) Lembang didirikan pada tanggal 8 Agustus 1971. Inisiasi awal pembentukan KPSBU Lembang karena posisi tawar (bargaining position) peternak sapi perah yang lemah dalam pemasaran susu akibat adanya kolektor yang sudah banyak menguasai pemasaran susu di Lembang. Perkembangan KPSBU Lembang selanjutnya mengalami kemajuan yang sangat pesat. KPSBU Lembang aktif menjalin kerjasama dengan berbagai stakeholders seperti kerjasama antara pemerintah Indonesia-Belanda dalam proyek HVA Internasional-PT. Frisian Flag Indonesia (FFI)-KPSBU. Selain itu KPSBU Lembang juga menjalin kemitraan CCA KPSBU dalam program INDOCAP Extension. Dalam hal penyediaan hijauan yang dibutuhkan peternak, KPSBU Lembang menjalin kerjasama dengan pihak PT. Perhutani berupa kesepakatan penggunaan lahan untuk penanaman makanan ternak.

Salah satu bagian penting dari berjalannya roda organisasi dan usaha KPSBU Lembang adalah keberadaan anggota.Jumlah anggota KPSBU Lembang cenderung meningkat setiap tahunnya.Pada tahun 2011, jumlah anggota KPSBU Lembang sebanyak 6.969 orang dan meningkat menjadi 7.293 orang pada tahun 2016. Hal ini karena berbagai fasilitas dan kemudahan yang disediakan oleh koperasi dalam mendukung kinerja usahaternak sapi perah anggotanya. Fasilitas yang disediakan bukan hanya fasilitas dan pelayanan untuk hewan ternak melainkan juga untuk peternak. Untuk menjadi anggota koperasi, peternak harus menjadi calon anggota terlebih dahulu dan mengikuti pendidikan dasar-dasar perkoperasian (Diksarkop).

Tabel 3.Perkembangan KPSBU Lembang Tahun 2012 s.d 2016

\begin{tabular}{lccccccc}
\hline Tahun & \multicolumn{2}{c}{$\begin{array}{c}\text { Perkembangan } \\
\text { organisasi }\end{array}$} & \multicolumn{3}{c}{ Perkembangan modal (Rp 000) } & \multirow{2}{*}{ SHU } \\
\cline { 2 - 7 } & Anggota & Produksi & S.Pokok & S.Wajib & S.Manasuka & S.Hari raya & \\
\hline 2012 & 6.930 & 46.703 .806 & 140.005 & 3.112 .453 & 1.474 .203 & 2.308 .870 & 1.514 .114 \\
2013 & 7.105 & 44.454 .206 & 140.825 & 3.249 .473 & 1.567 .203 & 3.116 .660 & 1.628 .850 \\
2014 & 7.091 & 47.379 .935 & 141.625 & 3.406 .165 & 1.666 .489 & 4.457 .030 & 1.956 .694 \\
2015 & 7.190 & 51.596 .314 & 143.825 & 3.790 .624 & 2.268 .697 & 6.123 .780 & 2.298 .348 \\
2016 & 7.293 & 55.165 .982 & 147.940 & 4.246 .197 & 2.910 .042 & 6.958 .575 & 2.450 .919 \\
\hline
\end{tabular}

Sumber: Laporan RAT KPSBU Lembang tahun 2012-2016

Tabel 3 memperlihatkan perkembangan KPSBU Lembang yang cukup baik dengan jumlah anggota, produksi, komponen simpanan dan SHU yang cenderung meningkat setiap tahunnya.Peningkatan tersebut sebagai salah satu indikator keberhasilan koperasi dalam pengelolaan bisnis nya yang berdampak pada meningkatnya jumlah anggota, volume usaha dan SHU.Peran KPSBU Lembang yang terbukti mampu mendukung kinerja usaha anggota menjadi insentif bagi peternak lainnya untuk bergabung di koperasi sehingga jumlah anggota, produksi dan volume usaha KPSBU Lembang mengalami peningkatan setiap tahunnya. 
Salah satu aspek yang penting untuk dicermati yaitu besaran SHU/liter susu dan SHU/anggota. Besaran SHU/liter susu bervariasi yaitu Rp 32,41-Rp 44,42/liter. Sedangkan besaran SHU/anggota juga terus mengalami peningkatan setiap tahunnya yaitu sebesar Rp 218.486,90-Rp 336.064,70. Jumlah ini jauh lebih besar dibandingkan temuan Asmarantaka (2012) yang menyatakan jumlah SHU/liter susu hanya sebesar Rp 16 dan SHU/anggota hanya sebesar Rp 71.500 pada penelitiannya yang dilakukan pada koperasi SAE Pujon. Nilai ini dapat menjadi salah satu indikator keberhasilan KPSBU Lembang dalam mengelola usaha secara efisien meskipun SHU tersebut tidak sepenuhnya diterima oleh peternak karena akan dialokasikan untuk akumulasi modal. Kemampuan KPSBU Lembang dalam mengelola usaha secara efisien merupakan kombinasi antara kemampuan dalam mengelola unit-unit usaha dengan baik dan efisiensi biaya.Efisiensi biaya KPSBU Lembang terlihat dari kenaikan biaya operasional yang masih dalam tahap wajar seiring dengan peningkatan volume usaha seperti terlihat pada Tabel 4.

Tabel 4. Perhitungan SHU KPSBU Lembang tahun 2012 s.d 2016 (Rp 000)

\begin{tabular}{lrrrrr}
\hline Uraian & \multicolumn{1}{c}{$\mathbf{2 0 1 2}$} & \multicolumn{1}{c}{$\mathbf{2 0 1 3}$} & \multicolumn{1}{c}{$\mathbf{2 0 1 4}$} & \multicolumn{1}{c}{$\mathbf{2 0 1 5}$} & \multicolumn{1}{c}{$\mathbf{2 0 1 6}$} \\
\hline Pend. Usaha & 257.423 .671 & 268.452 .670 & 319.910 .009 & 398.769 .464 & 403.269 .913 \\
HPP & 228.397 .998 & 236.458 .670 & 284.797 .307 & 348.794 .391 & 359.576 .191 \\
Pend. Kotor & 257.195 .273 & 31.994 .000 & 35.112 .702 & 40.975 .073 & 43.693 .721 \\
Pend. lain-lain & 822.342 & 721.682 & 857.277 & 1.294 .650 & 1.123 .213 \\
Total Pend. & 29.837 .015 & 32.715 .682 & 35.969 .979 & 42.269 .724 & 44.816 .935 \\
Beban usaha & 28.322 .900 & 31.086 .832 & 34.013 .284 & 39.971 .375 & 42.366 .015 \\
SHU sebelum & 1.514 .114 & 1.628 .850 & 1.956 .694 & 2.298 .348 & 2.450 .919 \\
pajak & - & - & - & - & 612.729 \\
Pajak & - & - & - & - & \\
SHU setelah & 1.514 .144 & 1.628 .850 & 1.956 .694 & 2.298 .348 & 1.838 .189 \\
pajak & & & & & \\
\hline
\end{tabular}

Sumber: Laporan RAT KPSBU Lembang tahun 2012-2016

Untuk menilai secara lengkap kemampuan koperasi dalam pengelolaan usaha dan keuangan maka penting untuk menganalisis kinerja keuangan KPSBU Lembang melalui analisis rasio likuiditas, rasio solvabilitas, ROI dan ROE. Berdasarkan Tabel 5, kondisi kinerja keuangan KPSBU Lembang dapat digolongkan tidak baik dengan rata-rata rasio likuiditas sebesar 124,52, rasio solvabilitas 65,58, ROI 2,69 dan ROE 8,40. Rasio-rasio tersebut berada dibawah kategori baik yang dipersyaratkan namun masih berada diatas batas minimum.Namun bukan berarti KPSBU Lembang tidak efisien dalam manajemen keuangan.Namun pertumbuhan SHU yang terus meningkat setiap tahunnya menjadi catatan positif dalam kinerja keuangan KPSBU Lembang.Selain itu, besaran biaya operasional masih dalam kategori wajar dan digunakan untuk kepentingan anggota. Hal in penting untuk diperhatikan karena tujuan koperasi adalah mensejahterakan anggotanya. Sebagai perbandingan, Asmarantaka (2012) dalam penelitiannya di koperasi SAE Pujon, Malang menemukan bahwa terjadi penurunan SHU setiap tahunnya karena kenaikan biaya operasional yang tidak berhubungan dengan usaha anggota yaitu pembayaran gaji karyawan yang terlalu besar.

Sebagai kelembagaan yang berperan penting dalam agribisnis sapi perah, KPSBU Lembang mengembangkan beberapa unit usaha untuk memenuhi kebutuhan anggota. Secara umum, unit usaha tersebut berhubungan langsung dengan kegiatan usaha anggota yaitu antara lain: (1) unit usaha produksi, pemasaran dan kualitas susu, (2) pakan konsentrat, (3) pengolahan susu, (4) warung serba ada, (5) peternakan sapi dan (6) perkreditaan.

Kegiatan utama KPSBU Lembang adalah menampung susu milik peternak untuk selanjutnya dipasarkan kepada industri pengolahan susu (IPS). Penjualan susu KPSBU Lembang didominasi penjualan ke IPS sekitar $90 \%$, penjualan eceran $9 \%$ dan produk olahan susu 1\%. Fenomena menarik yang perlu diperhatikan adalah terjadinya 
peningkatan jumlah penjualan susu ke IPS meningkat setiap tahunnya. Ketergantungan koperasi susu terhadap IPS dalam pemasaran susu menyebabkan koperasi susu tidak berdaya dalam penetapan harga susu. IPS yang menjadi pemasaran susu utama KPSBU Lembang adalah PT. Frisian Flag Indonesia (FFI) dan PT. Danone Dairy Indonesia.

Tabel 5. Kinerja Keuangan KPSBU Lembang Tahun 2012 s.d 2016

\begin{tabular}{lcccc}
\hline \multirow{2}{*}{ Tahun } & \multicolumn{4}{c}{ Indikator Kinerja Keuangan } \\
\cline { 2 - 5 } & Likuiditas & Solvabilitas & ROI & ROE \\
\hline 2012 & 127,28 & 61,01 & 2,99 & 7,67 \\
2013 & 130,75 & 61,74 & 3,07 & 8,03 \\
2014 & 128,05 & 64,67 & 2,88 & 8,15 \\
2015 & 118,91 & 69,85 & 2,77 & 9,20 \\
2016 & 117,61 & 70,65 & 2,63 & 8,97 \\
\hline
\end{tabular}

Sumber: Laporan RAT KPSBU Lembang tahun 2012-2016, diolah 2017

Selain memasarkan susu ke IPS, KPSBU Lembang juga menjual susu secara eceran dikantor koperasi dan mengolah susu menjadi berbagai produk olahan dengan merek dagang "Fresh Time". Pengolahan susu yang dilakukan KPSBU Lembang bertujuan untuk meningkatkan nilai tambah dibandingkan hanya menjual susu segar. Beberapa produk olahan yang ditawarkan oleh KPSBU Lembang yaitu youghurt, es yoghurt, pasteurisasi yoghurt, susu isam dan tahu susu. Namun jumlah susu segar yang dapat diserap oleh unit usaha ini masih sangat kecil karena permintaan terhadap produk olahan yang masih rendah.

Unit usaha lainnya KPSBU Lembang adalah produksi dan pemasaran pakan konsentrat. Kemudahan yang ditawarkan KPSBU Lembang adalah pembayaran konsentrat yang menyesuaikan siklus produksi dan proses pembayaran susu serta menawarkan jasa pengiriman langsung ke kandang peternak. KPSBU Lembang juga menyediakan warung serba ada (waserda) yang menyediakan kebutuhan sehari-hari peternak seperti sembako, obat-obatan, peralatan dan perlengkapan dalam usahaternak dll. Koperasi menawarkan kemudahan dengan jasa delivery dan pembayaran dapat dilakukan setelah uang pembayaran susu diterima oleh peternak.

KPSBU Lembang juga menyediakan usaha peternakan untuk menghasilkan bibit unggul sapi dan menerima penjualan anak sapi dari anggota.Bibit sapi tersebut dapat diperoleh dengan mengajukan kredit kepada koperasi sehingga peternak dapat mengembangkan usahanya yang berdampak pada meningkatnya pendapatan peternak. Namun dalam perjalanannya unit usaha ini juga menghasilkan susu yang juga menyumbang pendapatan bagi koperasi.

Unit usaha perkreditan koperasi membantu peternak untuk mendapatkan tambahan modal pengembangan usaha dan kebutuhan sehari-hari. Persyaratan untuk mendapatkan kredit sangat mudah dan jumlah kredit yang diambil disesuaikan dengan jumlah penerimaan susu peternak. Artinya hasil penjualan susu peternak harus mampu membayar kewajiban kredit setelah dipotong dengan biaya pakan dan waserda. Selain itu, proses administrasi pengajuan kredit di KPSBU Lembang sangat mudah dan pencairan kredit sangat cepat. Kredit yang disalurkan KPSBU Lembang merupakan kredit tanpa bunga dengan tujuan utama membantu peternak.

Selain unit usaha, KPSBU Lembang juga menyediakan beberapa jenis pelayanan yaitu pemeriksaan kesehatan hewan dan inseminasi buatan (IB), pelayanan tindakan bedah/operasi dan pelayanan program sapi bergulir mandiri. KPSBU Lembang menyediakan petugas medis hewan yang siaga 24 jam untuk melayani peternak terkait dengan masalah kesehatan sapi perah, penyakit dan penanganan sapi melahirkan. Untuk menikmati pelayanan tersebut, peternak tidak digunakan biaya namun untuk obat-obatan tetap harus membayar sesuai dengan obat yang digunakan.KPSBU Lembang juga melaksanakan tindakan bedah/operasi dalam menanggulangi penyakit sapi dislapsia dan operasi caesar. 
Untuk mendukung pengembangan usaha anggota, KPSBU Lembang mengadakan program sapi bergulir. Program ini dilaksanakan dengan memberikan sapi dara atau dara bunting kepada peternak untuk dipelihara dan kemudian bibit dari sapi tersebut akan digulirkan kepada peternak lainnya. Program ini bertujuan untuk menambah kepemilikan sapi perah dan selanjutnya akan berdampak pada keuntungan peternak. Program ini dirasakan sangat membantu peternak karena harga sapi yang mahal membuat peternak kesulitan dalam memperbesar skala usaha.

\section{Peran KPSBU Lembang}

Peran koperasi diukur dengan menggunakan teknik scoring berdasarkan lima indikator yang telah ditetapkan sebelumnya. Penilaian atas indikator tersebut merupakan persepsi anggota koperasi terhadap peran koperasi dalam mendukung kegiatan usaha anggota. Berdasarkan Tabel $6 \mathrm{KPSBU}$ Lembang sudah berperan dengan baik dalam mendukung keberlangsungan dan pengembangan usahaternak anggotanya yang terlihat dari rata-rata skor sebesar $89,22 \%$.

Tabel 6. Skor Penilaian Anggota Koperasi terhadap Peran KPSBU Lembang

\begin{tabular}{clc}
\hline No. & Jenis peran & Skor \\
\hline 1. & Dukungan produksi (production support) & 85,65 \\
2. & Dukungan pemasaran (marketing support) & 100 \\
3. & Representasi anggota (member representation) & 67,37 \\
4. & Pencatatan dan pengelolaan keuangan (finance and accounting) & 100 \\
5. & Manajemen kelompok (group management) & 93,05 \\
\hline & Rata-rata & $\mathbf{8 9 , 2 2}$ \\
\hline
\end{tabular}

Sumber: Data primer diolah, 2017

Peran KPSBU Lembang dalam bidang produksi dirasakan mendukung kinerja usahaternak anggota dengan berbagai layanan yang disediakan koperasi berupa menyediakan input produksi (konsentrat, IB, vitamin, obat-obatan, mineral dII), menyediakan fasilitas kredit, melakukan penyuluhan dan pembinaan mengenai budidaya sapi perah serta memfasilitasi bantuan pihak ketiga. Dalam bidang pemasaran, kehadiran KPSBU Lembang sebagai upaya untuk meningkatkan bargaining position peternak. Selain sebagai kolektor susu, peran KPSBU Lembang dalam bidang pemasaran antara lain menyediakan informasi pasar, transportasi susu dan cooling unit.

Kehadiran koperasi susu seharusnya dapat meningkatkan posisi tawar peternak terhadap industri pengolahan susu (IPS). Namun dalam kenyataannya, koperasi belum mampu menjadi representasi yang baik terutama untuk negosiasi harga susu dengan IPS yang terlihat dari skor penilaian anggota yaitu 67,37\%. Peternak dan koperasi susu tidak berdaya untuk menetapkan harga susu karena kualitas susu peternakan rakyat yang relatif tidak bagus dan persaingan dengan susu impor yang harganya lebih terjangkau.

Posisi peternak dalam pengelolaan usahanya merupakan seorang manajer.Seorang manajer harus mampu mengelola usahanya dengan efisien yang terlihat dari imbangan biaya dan penerimaan yang dihasilkan usaha. Untuk mengetahui hal tersebut, pencatatan dan pengelolaan keuangan usahaternak menjadi penting untuk dilakukan.Koperasi telah mampu berperan dengan baik dalam memberikan pelatihan kepada peternak untuk melakukan pencatatan keuangan usaha.Salah satu upaya yang telah dilakukan KPSBU Lembang yaitu melalui pencatatan produksi dan barang-barang yang diambil oleh peternak dari koperasi dan catatan tersebut diserahkan kepada peternak.Namun dalam aplikasinya, kesadaran peternak untuk melakukan pencatatan usaha masih sangat rendah.

Peran koperasi dalam manajemen kelompok dirasakan peternak sudah baik.KPSBU Lembang mampu merencanakan dan mempersiapkan kebutuhan belajar bagi angota, menyelesaikan konflik antar anggota, mengadakan rapat dan pertemuan secara rutin dan 
mengadakan berbagai penyuluhan dan pembinaan dalam rangka meningkatkan keterampilan teknis dan kapabilitas manajerial peternak.Hal ini mengindikasikan bahwa KPSBU Lembang berfungsi sebagai wadah belajar-mengajar bagi anggota guna meningkatkan pengetahuan, keterampilan dan sikap agar tumbuh dan berkembang menjadi peternak yang mandiri sehingga dapat meningkatkan produktivitas dan pendapatan.

Sejalan dengan hasil penelitian ini, Khan et al. (2014) mengungkapkan bahwa koperasi susu di India juga terbukti mampu sebagai enabler dalam proses pemberdayaan masyarakat pedesaan dan turut berkontribusi dalam pembangunan pedesaan. lebih lanjut dijelaskan bahwa di India koperasi susu merupakan organisasi penting karena memberikan harga yang adil dan pelayanan kepada peternak. Selain itu, koperasi susu adalah sumber utama penghasilan tetap untuk peternak sapi perah karena melakukan pembayaran susu secara bulanan sehingga dapat digunakan peternak untuk kegiatan produktif lainnya. Koperasi juga menyediakan perawatan kesehatan hewan yang diperlukan untuk meningkatkan kualitas ternak dan meningkatkan produksi susu. Simelane (2011) menambahkan bahwa koperasi sebagai wakil dari petani busa menjadi negosiator kuat dari seorang petani individu dalam pasar internasional.

\section{Struktur Biaya Usahaternak Sapi Perah Anggota KPSBU Lembang}

Biaya atau pengeluaran usahatani adalah nilai faktor produksi yang digunakan untuk menghasilkan output dalam waktu tertentu (Soekartawi et al., 2011). Pada penelitian ini, biaya digolongkan menjadi biaya tunai dan biaya diperhitungkan (non tunai).Biaya produksi yang dihitung merupakan biaya untuk sapi laktasi saja. Berdasarkan Tabel 7, komponen biaya terbesar dalam usahaternak sapi perah yaitu biaya pakan dengan persentase $80,09 \%$. Hal ini sesuai dengan penelitian Rahayu (2013); Haloho et al. (2013) dan Malau dan Winandi (2017). Jika dirinci berdasarkan jenis pakan, konsentrat merupakan pakan dengan persentase terbesar yaitu 46,02\%, disusul ampas tahu sebesar $16,77 \%$, hijauan $11,38 \%$ dan jerami $5,91 \%$. Besarnya biaya pakan yang dikeluarkan peternak artinya peternak harus selalu memperhatikan ketersediaan dan kualitas pakan agar kegiatan usaha dapat berjalan lancar.

Komponen biaya terbesar kedua yaitu tenaga kerja dengan persentase 15,60\%. Ditinjau dari sumber tenaga kerja yang digunakan maka penggunaan tenaga kerja dalam keluarga (TKDK) memiliki persentase terbesar dibandingkan tenaga kerja luar keluarga (TKLK).Biaya tenaga kerja dalam keluar seringkali tidak diperhitungkan oleh peternak karena peternak tidak mengeluarkan uang secara tunai untuk pembayaran upah.

Sebagai anggota koperasi, peternak mempunyai kewajiban untuk membayar beberapa kewajiban kepada KPSBU Lembang seperti simpanan wajib, simpanan manasuka, dana sosial dan dana rereongan. Besaran simpanan pokok dan dana sosial disesuaikan dengan jumlah susu yang dihasilkan oleh masing-masing peternak dengan nilai sebesar Rp 10/liter susu untuk simpanan wajib dan Rp 10/lier susu untuk dana sosial. Kewajiban lainnya yang harus dibayar anggota KPSBU Lembang yaitu simpanan manasuka sebesar $\mathrm{Rp}$ 10.000/peternak/15 hari dan danarereongan sebesar $\mathrm{Rp}$ 2.000/peternak/15 hari. Simpanan wajib dan manasuka dapat diambil oleh peternak setiap tahunnya sedangkan dana sosial digunakan untuk membantu peternak yang mengalami kemalangan. Dana rereongan digunakan untuk membantu peternak yang kesulita biaya untuk membeli sapi ketika sapi milik peternak tersebut mati.

Komponen biaya terbesar lainnya yaitu penyusutan peralatan dan perlengkapan yang digunakan dalam kegiatan usahaternak yaitu sebesar 2,19\%. Besarnya persentase biaya penyusutan dalam usahaternak sapi perah karena banyaknya perlengkapan dan peralatan yang harus dimiliki peternak dalam kegiatan budidaya seperti ember stainless, ember plastik, drum, karpet, selang, sabit, sekop, milk can, saringan, sikat dan masih banyak peralatan lainnya. 
Tabel 7. Rata-rata Biaya Produksi Usahaternak Sapi Perah 3,45 ST di KPSBU Lembang

\begin{tabular}{llrr}
\hline No & Uraian & Nilai (Rp) & Persentase (\%) \\
\hline 1. & Biaya tunai & & \\
\hline Konsentrat & 2.303 .497 & 46,02 \\
& Jerami & 295.999 & 5,91 \\
& Ampas & 839.514 & 16,77 \\
TKLK & 88.774 & 1,77 \\
Obat-obatan dan vitamin & 27.538 & 0,55 \\
Inseminasi buatan (IB) & 11.210 & 0,22 \\
Simpanan wajib & 152.64 & 0,31 \\
Simpanan manasuka & 100.00 & 0,20 \\
Dana sosial & 152.64 & 0,31 \\
Dana rereongan & 2.000 & 0,04 \\
& Listrik & 12.170 & 0,24 \\
& PBB & 12.025 & 0,24 \\
\hline & Total biaya tunai & 3.633 .259 & 72,59 \\
\hline Biaya diperhitungkan & & 11,38 \\
\hline & Hijauan & 569.644 & 13,83 \\
& TKDK & 692.421 & 2,19 \\
& Penyusutan peralatan dan & 109.766 & 27,41 \\
\hline & perlengkapan & 100 \\
\hline & Total biaya diperhitungkan & 1.371 .832 & \\
\hline 3. & Total biaya & 5.005 .092 & \\
\hline
\end{tabular}

Sumber: Data primer diolah, 2017

Gambaran struktur biaya pada Tabel 7 memperlihatkan bahwa usahaternak sapi perah merupakan usaha padat modal (capital intensive). Skala usaha peternakan sapi perah rakyat yang relatif belum ekonomis menyebabkan rendahnya produktivitas. Rendahnya produksi susu menyebabkan penerimaan yang diperoleh dari penjualan susu hanya memberikan keuntungan yang tipis atau hanya cukup untuk mempertahankan usahanya. Dalam hal ini peran koperasi sangat dibutuhkan melalui berbagai layanan usaha yang disediakan dalam mendukung pengembangan usahaternak sapi perah anggota.

\section{Penerimaan dan Pendapatan Usahaternak Sapi Perah Anggota KPSBU Lembang}

Penerimaan usahatani merupakan perkelian antara produksi yang dihasilkan dengan harga jual. Komponen penerimaan dalam penelitian ini terdiri dari penjualan susu segar ke koperasi, susu untuk pedet (anak sapi) dan susu untuk konsumsi keluarga. Berdasarkan Tabel 8, sumber penerimaan terbesar peternak berasal dari penjualan susu ke KPSBU Lembang dengan persentase 91,52 \%. Komitmen peternak untuk memasarkan susu melalui KPSBU Lembang sebagai dampak positif peran koperasi yang dirasakan mendukung kinerja usaha anggota. Pemasaran susu secara kolektif melalui koperasi secara signifikan akan menciptakan posisi tawar (bargaining position) yang lebih baik, meningkatkan keuntungan peternak dan meminimalisasi biaya transaksi. Penerimaan diperhitungkan dalam usahaternak sapi perah anggota KPSBU Lembang hanya dalam persentase yang relatif kecil yaitu sebesar $8,48 \%$ yang terdiri dari susu untuk pedet (anak sapi) sebesar 7,76\% dan susu untuk konsumsi keluarga sebesar $0,71 \%$. Rendahnya tingkat konsumsi susu oleh keluarga peternak karena peternak lebih menyukai susu kemasan dibandingkan susu segar. Pada umumnya, peternak menjual seluruh susu setelah dikurangi pemberian susu kepada pedet dengan alasan agar dapat menutupi kebutuhan biaya produksi. 
Tabel 8. Rata-rata Penerimaan Usahaternak Sapi Perah 3,45 ST di KPSBU Lembang

\begin{tabular}{llrr}
\hline No & Uraian & Nilai (Rp) & Persentase (\%) \\
\hline 1. & Penerimaan tunai & & \\
\hline & Susu ke KPSBU Lembang & 7.262 .485 & 91,52 \\
\hline 2. & Penerimaan diperhitungkan & & \\
\hline & Susu untuk pedet & 616.018 & 7,76 \\
& Konsumsi keluarga & 56.587 & 0,72 \\
& Total penerimaan diperhitungkan & 672.606 & 8,48 \\
3. & Total penerimaan & 7.935 .092 & 100 \\
\hline
\end{tabular}

Sumber: Data primer diolah, 2017

Selisih antara biaya produksi dan penerimaan akan memberikan gambaran mengenai tingkat pendapatan. Sedangkan perbandingan antara penerimaan dengan biaya ( $R / C$ rasio) akan memberikan gambaran efisiensi biaya. Tingkat pendapatan dan $\mathrm{R} / \mathrm{C}$ rasio dapat digunakan sebagai indikator untuk mengukur kinerja usahaternak sapi perah anggota KPSBU Lembang.

Tabel 9. Rata-rata Pendapatan dan R/C rasio Usahaternak Sapi Perah3,45 ST diKPSBU Lembang

\begin{tabular}{llr}
\hline No. & Uraian & Nilai \\
\hline 1. & Penerimaan tunai & 7.262 .485 \\
2. & Penerimaan diperhitungkan & 672.606 \\
3. & Total penerimaan & 7.935 .092 \\
4. & Biaya tunai & 3.633 .259 \\
5. & Biaya diperhitungkan & 1.371 .832 \\
6. & Total biaya & 5.005 .092 \\
7. & Pendapatan atas biaya tunai & 3.629 .226 \\
8. & Pendapatan atas total biaya & 2.930 .000 \\
9. & R/C atas biaya tunai & 2,13 \\
10. & R/C atas total biaya & 1,61 \\
\hline
\end{tabular}

Sumber: Data primer diolah, 2017

Melalui indikator besaran pendapatan dan R/C rasio dapat disimpulkan bahwa usahaternak sapi perah anggota KPSBU Lembang sudah menguntungkan baik atas biaya tunai dan total biaya (Tabel 9). Namun besaran pendapatan atas biaya tunai jauh lebih besar dibandingkan pendapatan atas total biaya. Hal ini disebabkan komponen biaya hijauan dan tenaga kerja dalam keluarga (TKDK) yang cukup besar yaitu $24,95 \%$ dari total biaya produksi. Peternak tidak mengeluarkan uang secara tunai untuk pembelian hijauan dan pembayaran upah tenaga kerja dalam keluarga (TKDK) namun biaya ini tetap harus diperhitungkan oleh peternak.Kondisi ini juga berpengaruh terhadap besaran $\mathrm{R} / \mathrm{C}$ rasio usahaternak sapi perah yang dijalankan oleh peternak. $\mathrm{R} / \mathrm{C}$ rasio atas biaya tunai sebesar 2,13 sedangkan $\mathrm{R} / \mathrm{C}$ rasio atas total biaya sebesar 1,61 . Dengan demikian dapat disimpulkan bahwa usahaternak sapi perah yang dijalankan oleh peternak anggota KPSBU Lembang menguntungkan. Beberapa penelitian juga mengungkapkan bahwa usahaternak sapi perah di Indonesia menguntungkan dan layak untuk dikembangkan seperti Malau dan Winandi (2017) di Kabupaten Bogor, Rahayu (2013) di Kabupaten Boyolali dan Haloho et al.(2013) di Kabupaten Semarang. R/C rasio usahaternak sapi perah anggota KPSBU Lembang lebih tinggi dibandingkan Malau dan Winandi (2017) di Kabupaten Bogor. Hal ini karena produktivitas susu yang dihasilkan peternak anggota KPSBU Lembang lebih tinggi karena suasana agroekosistem Lembang yang masih cukup mendukung untuk peternakan sapi perah. 


\section{SIMPULAN}

KPSBU Lembang berkembang dengan pesat yang terlihat dari pertambahan jumlah angota, produksi susu, modal, SHU dan volume usaha. Unit-unit usaha yang dikembangkan KPSBU Lembang juga berhubungan langsung dengan kegiatan usaha para anggotanya.Meskipun kinerja keuangannya tergolong kurang baik, namun secara umum masih berada dalam kategori wajar dan relatif efisien.Penilaian dari peternak juga memperlihatkan bahwa peran KPSBU Lembang dirasakan sangat mendukung kinerja dan pengembangan usahaternak. Hal ini terlihat dari kinerja usahaternak sapi perah anggota KPSBU Lembang yang menghasilkan besaran pendapatan dan $\mathrm{R} / \mathrm{C}$ rasio positif artinya usahaternak sapi perah tersebut layak dan menguntungkan. Hasil penelitian ini membantu mengkonfirmasi bahwa upaya meningkatkan produksi susu nasional dapat diwujudkan melalui pengoptimalan peran koperasi susu. Oleh karena itu, koperasi susu perlu mendapat dukungan dari pemerintah dan pihak terkait terutama berkaitan dengan peningkatan bargaining power dalam penentuan harga input dan output.

\section{DAFTAR PUSTAKA}

Ariningsih, E. (2014). Impacts of Cooperative Membership on Sugarcane Farmers Incomes in East Java Province. Jurnal Agro Ekonomi. 32(2): 147-165.

Asih, R., Murti, T.W., \& Haryadi, F.T. (2013). Dinamika Pengembangan Klaster Industri Persusuan di Kabupaten Semarang, Jawa Tengah. Buletin Peternakan. 37(1): 59-66.

Asmara, A., Purnamadewi, Y.L., Lubis, D. (2016). Keragaan Produksi Susu dan Efisiensi Usaha Peternakan Sapi Perah Rakyat di Indonesia. Jurnal Manajemen \& Agribisnis. 13(1): 14-25

Asmarantaka, R.W. (2012). Peranan dan Analisis Pendapatan Koperasi Susu di Jawa Timur (Kasus Koperasi Peternak Sapi Perah SAE Pujon). Scientific Repository, IPB University, Bogor.

Haloho, R.D., Santoso, S.I., \& Marzuki, S. (2013). Analisis Profitabilitas pada Usaha Peternakan Sapi Perah di Kabupaten Semarang. Jurnal Pengembangan Humaniora. 13(1): 65-72.

Hermanto \& Swastika, D.K.S. (2011). Penguatan Kelompok Tani: Langkah Awal Peningkatan Kesejahteraan Petani. Analisis Kebijakan Pertanian. 9(4):371-390.

Khan, N. Parashari, A.K, Salman, M.S. 2014. Role of Dairy Co-operatives in SocioEconomic Development of Dairy Farmers in Moradabad District: A Case Study. International Journal of Social. 2(1): 1-18

Makin. (2011). Tata Laksana Peternakan Sapi Perah. Yogyakarta, ID: Penebar Swadaya.

Malau, L.R.E., \& Winandi, R. (2017). Pendapatan Usahaternak Sapi Perah Anggota KPS Bogor (Kasus: Kunak Cibungbulang dan Kelurahan Kebon Pedes). Forum Agribisnis. 7(1): 67-84.

Munawir. (1995). Analisis Laporan Keuangan. Yogyakarta (ID): Liberty

Ortmann, G.F., \& King, R.P. (2007). Agricultural Cooperatives: History, Theory and Problems. Agroekon. 46(1): 40-68.

[Pusdatin] Pusat Data dan Sistem Informasi Pertanian. (2019). Buku Outlook Komoditas Peternakan Susu Sapi. Jakarta: Kementerian Pertanian.

Rahayu, E.T. (2013). Analisis Pendapatan Usaha Ternak Sapi Perah di Kecamatan Cepogo Kabupaten Boyolali.Sains Peternakan. 11(2): 99-105. 
Sarker, D., \& Ghosh, B.K. (2011). Constraints of Milk Production: A Study on Cooperative and Non-Cooperative Dairy Farms in West Bengal. Agricultural Economic Research Review. 23(1): 303-314.

Sartono, A. (2015). Manajemen Keuangan: Teori dan Aplikasi,Edisi keempat. Yogyakarta (ID): BPFE

Simelane, N. (2011). An Assesment of The Role Of Cooperative in Smallholder Dairy production and Marketing in Swaziland, Thesis. Pretorial (SA): University of Pretoria

Soekartawi., Soeharjo, A., Dillon, J.L., \& Hardaker, J.B. (2011). Ilmu Usahatani dan Penelitian untuk Pengembangan Petani Kecil. Jakarta (ID): UI Press.

Sonam, T., \& Martwanna, N. (2013). Perfomance of Smallholder Dairy Farmers Groups in The East and West Central Regions of Bhutan: Member Perspective. Journal of Agricultural Extension and Rural Development. 4(1): 23-29.

Sulastri, E., \& Maharjan, K.L. (2002).Role of Dairy Cooperative Services on Dairy Development in Indonesia (A Case study of Daerah Istimewa Yogyakarta Province). Journal of International Development and Cooperation. 9(1): 18-39.

Syarif, E.K., \& Harianto, B. (2011).Buku Pintar Beternak dan Bisnis Sapi Perah. Jakarta, ID: Agromedia Pustaka.

Utami, A.W., Salman, L.B., Firman, A. (2020). Analisis Efisiensi Teknis pada Usaha Sapi Perah di Kecamatan Tanjungsari. Mimbar Agribisnis. 6(1): 254-264. 